Beata Kubiak Ho-Chi

Uniwersytet Warszawski

\title{
Krajobrazy posthumanistyczne w prozie Hiromi Kawakami
}

Hiromi Kawakami (ur. 1958), uznana współczesna pisarka japońska, tworzy w swoich powieściach i opowiadaniach, określanych jako „opowieści zmyślone", oryginalny świat fantazji, zamieszkiwany na równych prawach przez ludzi i byty nie-ludzkie. Co charakterystyczne, ich uniwersa przenikają się, sprawiając, że zacierają się między nimi granice taksonomiczne, estetyczne, etyczne. W wyniku przesunięcia uwagi z człowieka na inne ssaki, gady, płazy, rośliny, jak również materię nieożywioną, ludzki podmiot ulega w utworach Kawakami decentracji, a antropocentryczny porządek normatywny zostaje całkowicie zaburzony. Pozwala to na interpretację jej prozy w kontekście myśli posthumanistycznej, zajmującej ważne miejsce w rozwijającej się w ostatnich latach humanistyce środowiskowej.

W niniejszym artykule przyjrzę się wybranym utworom Kawakami jako świadectwu obecności we współczesnej literaturze japońskiej tematów niezwykle

1 Do nurtu „opowieści zmyślonych” (jap. usobanashi) Kawakami należą (oprócz utworów analizowanych w tym artykule), m.in. Tokage (Jaszczurka, 1995), Znikaja (Kieru, 1996), Zapiski z pewnej niezwykłej nocy (Atarayoki, 1996), Hanasanai (Nie zostawię cię, 1998), Yashi yashi (Dobla noc, 1998), Kamimushi (Boski owad, 1999), Hokusai (Hokusai, 2001) i wiele innych. Do drugiego nurtu twórczości Kawakami zaliczają się utwory, których tematem jest codzienność zwykłych ludzi, z ich miłościami, troskami i smutkami, m.in. powieści Sensei i miłość (Sensei no kaban, 2001), Pan Nakano i kobiety (Furudōgu Nakano shoten, 2005). 
istotnych dla człowieka doby antropocenu. Należeć do nich będą m.in. takie zagadnienia, jak waga harmonijnego współistnienia w naszym świecie istot ludzkich i nie-ludzkich, związek natura - kultura czy też świadomość ekologiczna w dobie katastrof naturalnych i atomowych. Do analizy wybrałam kilka utworów Kawakami, gatunkowo oscylujących pomiędzy baśnią a fikcją spekulatywną. Należeć do nich będzie powieść Nadepnęłam na węża (Hebi o fumu, 1996) oraz opowiadania Niedźwiedzi bóg (Kamisama, 1994), Sōjō no chūshoku (Lunch na trawie, 1998), Ugoromochi (Kret, 2001) i Niedźwiedzi bóg 2011 (Kamisama 2011, 2011). Stanowią one niewielką część twórczości Kawakami, za którą otrzymuje w kraju prestiżowe nagrody literackie, za granicą należy zaś do najczęściej tłumaczonych współczesnych pisarek japońskich ${ }^{2}$.

Zawarte w tytule mojego artykułu „krajobrazy posthumanistyczne” odnosić się będą przede wszystkim do ukazanych w prozie Kawakami sytuacji i relacji pomiędzy ludźmi i nie-ludźmi, dla których kontekstem stanie się myśl posthumanistyczna, a w szczególności posthumanizm krytyczny³.

Trzon tego nurtu filozoficznego, wyrosłego $\mathrm{z}$ tradycji powojennego antyhumanizmu ${ }^{4}$, stanowi antyantropocentryzm, który, odrzucając uprzywilejowaną pozycję człowieka w świecie, przekierowuje uwagę na byty nie-ludzkie. Należą do nich inne niż człowiek zwierzęta, nad którymi badania rozwijają się w ramach animal studies ${ }^{5}$ (przedstawiciele posthumanizmu krytycznego poświęcają im

2 Kawakami jest laureatką kilkunastu najważniejszych japońskich nagród literackich, w tym Nagrody Akutagawy za Nadepnęłam na węża, Nagrody Tanizakiego za Sensei i mitość, Nagrody Mishimy, Itō Seia i in. Sama też zasiada w jury kilku nagród literackich. Na polski przetłumaczone zostały jej trzy powieści: Manazuru, Sensei i miłość, Pan Nakano i kobiety, a także dwa zbiory: Nadepnęłam na węża i Niedźwiedzi bóg.

3 We współczesnej myśli posthumanistycznej wyróżnić można, według Rosi Braidotti, należącej do głównych filozofek posthumanistycznych przełomu XX i XXI wieku, trzy główne nurty: posthumanizm reaktywny, posthumanizm analityczny i posthumanizm krytyczny (zob. Braidotti 2014: 103-122).

4 Wliczyć tu można zarówno antyhumanistyczne postawy czołowych myślicieli XX wieku, takich jak Michel Foucault, Jacques Derrida czy Roland Barthes, którzy ogłosili, kolejno, „śmierć człowieka”, „kres człowieka” i „śmierć autora” (zob. Bakke 2010: 25), jak również myśl filozofów poststrukturalizmu, feministycznego antyuniwersalizmu oraz antykolonialnej fenomenologii - Aimé Césaire’a i Frantza Fanona (zob. Braidotti 2014: 115).

5 Szczególne miejsce zajmują tu filozofowie występujący w obronie praw zwierząt, tacy jak Peter Singer (zob. Singer 2004, 2011, red.), Tom Regan (zob. Regan 1980) czy twórca koncepcji szowinizmu gatunkowego, Richard Ryder (zob. Ryder 1980). Doskonałą syntezę myśli na temat zwrotu zwierzęcego w naukach humanistycznych, animal studies $\mathrm{i}$ ich znaczącego miejsca w posthumanizmie prezentuje również Kari Weil w artykule Zwrot ku zwierzętom. Sprawozdanie (zob. Weil 2014). 
wiele uwagi, zob. np. Wolfe 2010, 2013; Haraway 2008, 2012), a także rośliny i mikroorganizmy, powiązane z człowiekiem witalną siłą nieskończonego życia zoe i współistniejące $\mathrm{w}$ przyrodzie w relacjach podmiotowych (zob. Braidotti 2006: 35, 2014: 121-122; Bakke 2012: 38-40). Do bytów nie-ludzkich zaliczana jest też materia mineralna (geos), z której wyłoniło się życie biologiczne (zob. Bakke 2020: 165-169) oraz posiadające funkcje sprawcze rzeczy (zob. Gajewska 2013: 45-59).

Tego typu spojrzenie na miejsce człowieka w posthumanistycznym świecie prowadzi do zakwestionowania esencjalistycznego pojęcia natury i zanegowania, obecnego dotychczas w myśli zachodniej, tradycyjnego podziału na naturę i kulturę - granica pomiędzy nimi zostaje zniesiona i natura postrzegana jest jako produkt kulturowy (Soper 2014: 38). Podejście to łączy najważniejszych teoretyków posthumanizmu krytycznego, do których należą Rosi Braidotti, Dona Haraway, Cary Wolfe, Bruno Latour, a z polskich naukowców Monika Bakke, Ewa Domańska czy Anna Barcz. W swoich pracach zadają oni ważne dla współczesnego człowieka pytania o świat, który postczłowiek współtworzy $\mathrm{z}$ bytami pozaludzkimi.

\section{Inspiracje przyrodnicze i literackie Kawakami a nie-ludzka tematyka jej utworów}

Można sobie zadać pytanie, skąd bierze się predylekcja Kawakami do tematyki literackiej ukierunkowanej na istoty inne niż ludzkie. Częściowej odpowiedzi dostarcza przyrodnicze wykształcenie pisarki. Podczas gdy większość ludzi pióra wywodzi się ze środowisk związanych z naukami humanistycznymi, Kawakami ma w swoim curriculum vitae studia w Zakładzie Biologii Wydziału Nauk Przyrodniczych Żeńskiego Uniwersytetu Ochanomizu (Ochanomizu Joshi Daigaku Rigakubu Seibutsugaku) w Tokio ${ }^{6}$. Ich zwieńczenie stanowiła praca magisterska poświęcona tematowi mobilności plemników jeżowców (echinoidea), czyli niewielkich bezkręgowych zwierząt morskich, należących do typu szkarłupni. To tłumaczy, dlaczego tematyka życia w jego wszelkich przejawach i stadiach rozwojowych, mechanizmów ewolucyjnych czy budowy komórek jest jej równie bliska jak zagadnienia dotyczące człowieka i jego kulturotwórczej aktywności.

O wadze zainteresowania Kawakami biologią świadczy również fakt, że po ukończeniu Uniwersytetu Ochanomizu kolejne dwa lata spędziła w Instytucie Nauk Medycznych Uniwersytetu Tokijskiego (Tōkyō Daigaku Ikagaku Kenkyūjo). To zamiłowanie do wiedzy biologicznej odziedziczyła po ojcu,

6 W Żeńskim Uniwersytecie Ochanomizu studiowała w latach 1976-1980. 
profesorze biologii na Uniwersytecie Tokijskim. I choć sama nie związała życia zawodowego z uczelnią, przez cztery lata była nauczycielką przyrody w jednym z tokijskich liceów (Uei 2005: 147). Nie czuła się jednak stworzona do zawodu nauczycielskiego, o czym $\mathrm{z}$ humorem pisała w jednym ze swoich opowiadań autobiograficznych? . Bliższy był jej zawsze świat fikcji literackiej, na którego kreację - jak sama przyznaje - jej wiedza biologiczna ma wpływ:

Gdy piszę powieść, zastanawiam się nad tym, czym jest człowiek. Co się stanie, gdy będzie dużo ludzi, ze mną włącznie. Jak będą wyglądały stosunki między nimi - zawsze mam to w głowie podczas pisania. Oczywiście można do tego podejść na sposób literacki, ale biologia jest nauką, która każe myśleć o relacjach w przyrodzie żywej istoty, jaką jest człowiek, z innymi zwierzętami i roślinami; o tym, do jakich systemów należą, jak funkcjonują itd. W pewnym sensie to wszystko wpływa na sposób myślenia osoby, która pisze (Kawakami, Numano 2012) ${ }^{8}$.

Kawakami zasiedla więc swoje powieściowe światy nie tylko ludźmi, ale tė̇ niedźwiedziami, kretami, wężami, ośmiornicami, konikami morskimi, współtworzącymi wraz z człowiekiem królestwo zwierząt. Zdając sobie przy tym sprawę $\mathrm{z}$ niewielkiego znaczenia jednostkowych bytów w obliczu potęgi natury, docenia wartość każdego istnienia i jego moc sprawczą, na zasadzie Latourowskiego kolektywu aktorów - zrzeszeń ludzi i nieludzi nieustannie wpływających na siebie w wyniku swoich działań (Latour 2009: 313, 328). Potwierdza tym wpływ świadomości przyrodniczej nie tylko na sposób, w jaki kreuje swoje światy powieściowe, ale też na własny światopogląd:

Dla mnie „ja” nie jest czymś specjalnym, „ja” jest maleńkim elementem natury; czy ego jest, czy go nie ma, świat i tak będzie istniał. Ale to nie znaczy, że bycie takim elementem jest czymś nieważnym - każdy element ma swój własny punkt widzenia (Kawakami, Numano 2012).

Uwrażliwienie na zjawiskowy świat natury oraz postrzeganie zmysłowe, zauważalne w sposobie, w jaki Kawakami tworzy rzeczywistość powieściową, nasuwa również skojarzenia z tradycyjną japońską poezją waka, a w szczególności $\mathrm{z}$ jej najkrótszą formą, haiku. W tym skondensowanym, siedemnastosylabowym

7 O swoim nieprzystosowaniu do zawodu nauczyciela pisze w opowiadaniu Hazuki san no koto (Pani Hazuki), zob. Kawakami 2009: 172-173.

8 Tłumaczenia tekstów obcych, o ile nie zaznaczono inaczej, pochodzą od autorki artykułu. 
wierszu wszelkie uczucia ludzkie - smutek, samotność, radość, miłość - nie są wyrażane bezpośrednio, lecz poprzez odwołania do zjawisk przyrody wraz z jej zwierzęcymi i roślinnymi przejawami, obecnymi w powtarzającym się odwiecznie cyklu czterech pór roku. I to właśnie haiku, w którym człowiek stapia się w jedno z przyrodą, stanowiąc jeden $\mathrm{z}$ wielu elementów naturalnego krajobrazu, jest ulubioną formą poetycką Kawakami. W 1994 roku, kiedy to zadebiutowała krótkim, nasuwającym na myśl haiku, opowiadaniem Niedźwiedzi bóg ${ }^{9}$, została również członkiem internetowego Stowarzyszenia Haiku (Uei 2005: 148). Na swoim koncie ma zbiór trzystu haiku, zatytułowany Kigen no ii inu (Pies $w$ dobrym humorze, 2010).

\section{Inny wśród nas - Niedźwiedzi bóg}

„Powieści o odmiennych gatunkach” (ishu shōsetsu), historie o ,istotach $\mathrm{z}$ innego świata” (bessekai no ikimono) - słowo „odmienny”, „inny” używane jest często na określenie prozy Kawakami (zob. Shimizu 2003: 73). Inność odnosi się w tym wypadku przede wszystkim do innego niż homo sapiens gatunku istot żywych bądź bytów nieożywionych. Bywa przy tym jednocześnie figurą Innego - obcego, nieznanego czy to zwierzęcia, czy człowieka, którego obecność w „normalnym” świecie zaburza zastany porządek i wzbudza różne, często negatywne emocje. Wejście do tego „normalnego”, rzeczywistego świata, który jest człowiekowi znany, z jego codziennymi zdarzeniami i problemami, prowadzi w opowiadaniach Kawakami właśnie poprzez ten inny świat.

Wzorcowym opowiadaniem tego typu, stanowiącym rodzaj matrycy „opowieści zmyślonych” Kawakami, jest wspomniany Niedźwiedzi bóg. Pisarka streszcza je następująco:

Jest to króciutkie opowiadanie, zajmujące ledwie dziesięć stron arkusza czterystuznakowego. Gdybym miała je streścić dla kogoś, kto go nie zna, jest to prosta opowieść o zaproszeniu na przechadzkę nad rzekę przez dobrze wychowanego niedźwiedzia, który pewnego dnia zamieszkał w sąsiedztwie; o zjedzeniu prowiantu i powrocie do domu. Niedźwiedź

9 Kawakami otrzymała za to opowiadanie w 1994 roku internetową Nagrodę Pascala dla Debiutantów. W formie papierowej Niedźwiedzi bóg, wraz z ośmioma innymi wczesnymi opowiadaniami tej pisarki, został zamieszczony w zbiorze o tym samym tytule, wydanym po raz pierwszy przez wydawnictwo Chūō Kōron w 1998 roku. Za zbiór ten Kawakami otrzymała dwie nagrody literackie, Bunkamura Deux Magots i Nagrodę Murasaki Shikibu. 
jest też symbolem mniejszości - i jest to smutne - ale poza tym to zupełnie zwykłe, spokojne opowiadanie (Kawakami, Numano 2012).

Kawakami nie precyzuje, o jakie mniejszości chodzi, lecz prawdopodobne wydaje się, że ma na myśli Ajnów, rdzennych mieszkańców Wysp Japońskich. Ajnowie, zamieszkujący współcześnie głównie Hokkaido, wyznają animizm, w którego centrum znajduje się kult niedźwiedzia. Dyskryminowani przez rząd japoński, od lat walczą o swoje prawa do kultywowania języka, kultury i bogatej tradycji. Lecz niedźwiedź równie dobrze może symbolizować inne zamieszkujące Japonię i w różny sposób dyskryminowane mniejszości narodowe, licznie reprezentowane przez Koreańczyków i Chińczyków. Jest też przedstawicielem każdego nie-ludzkiego zwierzęcia tworzącego wspólnie z człowiekiem posthumanistyczny, wielogatunkowy świat.

Prostota opowiadania, o której mówi jego autorka, jest złudna. W rzeczywistości Niedźwiedzi bóg jest utworem pełnym ukrytych znaczeń, poddającym się wielorakim interpretacjom. Jego bogactwo semantyczne i wartości etyczne, które w sobie kryje, sprawiły, że znalazł się w wypisach do literatury japońskiej dla szkół średnich.

W opowiadaniu tym została zastosowana narracja trzecioosobowa. Narratorka - przypuszczać można, że to młoda kobieta, lecz w rzeczywistości ani wiek, ani płeć nie są tu zasugerowane - w bardzo spokojnym tonie opowiada o miłym dniu, spędzonym wspólnie nad rzeką z niedźwiedziem. Niedawno wprowadził się na to samo piętro, na którym mieszka narratorka, trzy drzwi od niej. Mają wspólnych ludzkich znajomych (o czym ze wzruszeniem informuje ją niedźwiedź), lecz o samym niedźwiedziu narratorka może jedynie powiedzieć, że jest bardzo dużym, dorosłym samcem. Przyznaje, że nie zna się na zwierzętach i nie wie, do jakiego gatunku niedźwiedź należy - może jest to niedźwiedź księżycowy, brunatny, a może malajski - ale z jego grzecznego zachowania wnioskuje, że jest dobrze wychowany. Nad rzeką, gdzie było mnóstwo kąpiących się ludzi, wykazał się cierpliwością i wyrozumiałością wobec natrętnych gapiów. Zręcznie złowił rybę, ze znawstwem oprawił ją i ususzył na słońcu, by potem sprezentować ją swojej towarzyszce. Po wspólnym zjedzeniu lunchu, który niedźwiedź sam przygotował, z troską zaproponował, by się zdrzemnęła, a nawet chciał jej zaśpiewać kołysankę. Po miło spędzonym dniu oboje wrócili do domu. Przed drzwiami narratorki niedźwiedź podziękował za udany dzień, lekko zmieszany przytulił ją (po uzyskaniu wcześniejszej zgody na ten, bądź co bądź intymny, gest) i polecił opiece niedźwiedziego boga. Przed snem narratorka spróbowała go sobie wyobrazić, lecz nie potrafiła i ostatecznie stwierdziła: „To był całkiem niezły dzień” (Kawakami 2019a: 33 ). 
Spotkanie kobiety i niedźwiedzia przebiega w opowiadaniu tak naturalnie, jakby to było spotkanie dwojga sympatycznych, miłych dla siebie ludzi. Kobiety nie zdumiewa fakt, że jej sąsiad jest zwierzęciem, że zaprosił ją na spacer i zachowuje się jak człowiek. Narratorka uosabia swoim zachowaniem afirmatywną wizję świata, w którym panuje dobrosąsiedzka życzliwość, uprzejmość i gościnność. Przejawia się ona w bezwarunkowym akceptowaniu Innego w swoich progach, co przywołuje na myśl koncepcję gościnności nieskończonej Jacques'a Derridy. Filozof zastanawia się nad potencjalnym jej istnieniem w kontekście palących problemów imigracyjnych, integracji cudzoziemców, grup etnicznych i granic państwowych:

W gościnności bezwarunkowej - mówi Derrida - gospodarz powinien w zasadzie przyjmować gościa, zanim dowie się czegokolwiek o nim. Czyste przyjmowanie polega nie tylko na tym, by nie wiedzieć lub działać, jakby się nie wiedziało, ale na unikaniu wszelkich pytań na temat tożsamości innego, jego pragnienia, jego reguł, języka, zdolności do pracy, integracji czy adaptacji (Derrida 2004: 257).

I tak też zachowuje się narratorka Niedźwiedziego boga - nie zadaje żadnych pytań oprócz tego, jak ma się do niedźwiedzia zwracać. Akceptuje zaproszenie Innego, wpuszczając go w swoją własną, osobistą przestrzeń; poświęca mu czas, przyjmuje dar, a nawet akceptuje opiekę jego boga. $\mathrm{W}$ tym sensie człowiek i niedźwiedź tworzą niemal idealny kolektyw współistniejących ze sobą istot ludzkich i nie-ludzkich, w którym gdzieś głęboko pobrzmiewają echa ajnoskiego mitu o niedźwiedzim bogu, wielkim, silnym, wzbudzającym podziw i respekt. Podobnie jak w Japonii przednowoczesnej, brak tu rozróżnienia na wykluczające się nawzajem naturę - reprezentowaną przez niedźwiedzia - i kulturę - jednoznacznie kojarzoną z człowiekiem. Do takiego właśnie spojrzenia na naturę, która przenika się z kulturą, tworząc niedychotomiczną naturę-kulturę, czy wręcz naturękulturę, przekonują filozofowie posthumanistyczni (por. Latour 2009: 69-78, Bakke 2010: 57-66).

A jednak, na miłym i pozornie tylko nieskończenie gościnnym świecie Niedźwiedziego boga, w którym człowiek i zwierzę zgodnie spędzają ze sobą czas, pojawiają się rysy. W rzeczywistym świecie trudno jest bowiem przełożyć czystość etyki gościnności bezwarunkowej na zasady polityczne, na prawo, gdyż obawa przed Innym wzbudza często niepokój, a nawet nienawiść (Derrida 2004: 258). Pierwsza, jeszcze delikatna rysa pojawia się, gdy narratorka zdaje sobie sprawę, że niedźwiedź zmuszony jest wkupić się w łaski swoich sąsiadów, by uzyskać ich akceptację. Robi to, wręczając im na powitanie makaron gryczany 
i widokówki. Ten stary zwyczaj, praktykowany w dawnej Japonii, zostaje oceniony przez narratorkę jako „rzadkość w ostatnich czasach”, uprzejmość, która nie zdarza się często, jednak „gdy się jest niedźwiedziem, należy mieć tego typu rzeczy na uwadze" (Kawakami 2019a: 23). Jednym słowem, Inny musi się bardziej postarać, zrobić większy wysiłek, by być przez gospodarza tolerowanym (nie mówiąc już o pełnej aprobacie jego obecności w tej samej przestrzeni, bądź o równych prawach).

Ale i tolerancja nie jest postawą powszechną - druga, dużo mocniejsza już rysa, przecinająca gładką powierzchnię współdzielonego przez niedźwiedzia i ludzi świata, pojawia się, gdy nad rzeką do narratorki i niedźwiedzia podchodzi dwóch mężczyzn z dzieckiem. Są jednymi z wielu ludzi, którzy w skwarny dzień zażywają tutaj ochłody. Przebywający wśród nich niedźwiedź najwyraźniej zaburza ich poczucie „normalności”. Mężczyźni, stojąc przy nim, nie odzywają się i omijają go spojrzeniem, natomiast dziecko, po kilkakrotnym okrzyku zdziwienia na widok zwierzęcia, „ciągnie niedźwiedzia za futro i kopie go, aż w końcu z okrzykiem «A masz!» - wali go pięścią w brzuch i ucieka” (Kawakami 2019a: 27). Narratorka pozostaje bierną obserwatorką, natomiast niedźwiedź wielkodusznie tłumaczy zachowanie dziecka: „Mali ludzie nie robią takich rzeczy złośliwie. [...] Oczywiście ludzie są różni, ale dzieci są niewinne” (Kawakami 2019a: 27). Stara się w ten sposób przejść do porządku dziennego nad sytuacją, w której został pozbawiony godności, a jego równoprawne miejsce w ludzkim świecie uległo zakwestionowaniu.

Zwierzęcy bohater Niedźwiedziego boga, choć świadomy swojej inności i wywoływanej przez nią nie zawsze przychylnej reakcji, pozostał w świecie ludzi. Ale już w kontynuacji tego opowiadania, jaką stanowi napisany kilka lat później Lunch na trawie ${ }^{10}$, niedźwiedź decyduje się na powrót w rodzinne strony. Podczas ostatniego spaceru, na który zaprasza swoją sąsiadkę, przyznaje, że nie jest w stanie zaadaptować się do życia w świecie ludzkim. Jego towarzyszka, która tym razem nieco częściej ujawnia swoje uczucia, jest smutna. Nie widzi potrzeby, by niedźwiedź przestrzegał wszystkich ludzkich zwyczajów, i sama, jak twierdzi, nie do wszystkiego w tym świecie przywykła. A jednak zauważa znaczącą inność niedźwiedzia. Gdy na dźwięk odgłosu nadchodzącej burzy niedźwiedź wydaje groźny ryk, ogarnia ją strach. Oboje dochodzą wtedy do wniosku, że niedźwiedź i człowiek jednak się od siebie różnią. Stojąc na wzgórzu i podziwiając zachód słońca, milczą. Możemy podejrzewać, że myślą o tym, co ich dzieli, o różnicach wartości, które są nie do pokonania (Araki 2011: 224 (9)). Rozstają się, tym razem na zawsze. Ich pożegnanie nie jest już tak wzruszające jak w pierwszym opowiadaniu. Mimo to, gdy po jakimś czasie przychodzi list 
od niedźwiedzia, napisany raczej formalnym językiem, w oczach jego dawnej sąsiadki pojawiają się łzy. Czytając list trzykrotnie, zadaje sobie pytania o niedopasowanie niedźwiedzia do świata ludzi, lecz nie znajduje na nie odpowiedzi. Tym razem jest jednak pewna, że bóg niedźwiedzi wygląda zupełnie inaczej niż bóg ludzki - pierwszy jest jak niedźwiedź, drugi - jak człowiek.

Oba opowiadania, oprócz interpretacji w kategoriach Innego, odczytywać można również $\mathrm{w}$ kontekście rozpadu więzi społecznych w ponowoczesnym społeczeństwie, zjawiska nasilającego się w Japonii szczególnie od lat dziewięćdziesiątych XX wieku. Niedźwiedź reprezentuje dawny, wspólnotowy sposób bycia - stara się stworzyć relacje z członkami społeczności, wśród której zamieszkał, przestrzegać zwyczajów panujących wśród ludzi. Pragnie zbudować więzi (tsunagari, kizuna), bliskość (najimi), wykazując się przy tym empatią i atencją w stosunku do innych (zob. Araki 2011: 230 (3)). Za takim światem tęsknimy, takie relacje powinniśmy budować, niezależnie od tego, jak bardzo się od siebie różnimy - zdaje się mówić w swym opowiadaniu Kawakami z pozycji postczłowieka, który respektuje każdego Innego, bez względu na to, czy jest to inny człowiek, czy istota nie-ludzka.

\section{Transgatunkowe relacje dalsze i bliższe - Nadepnętam na węża}

Nieznająca granic gatunkowych wyobraźnia Kawakami podsuwa jej wizje posthumanistycznego świata, w którym spotkania $\mathrm{z}$ istotami innymi niż ludzie dotykają również sfery cielesnej. Zbliżenia z nie-ludzkimi ciałami, te pozostające w sferze kontaktów przyjacielskich czy rodzinnych, ale też i takie, które przełamują tabu transgatunkowych relacji intymnych, odnajdujemy w powieści Nadepnęłam na węża. Narratorka, młoda kobieta o imieniu Hiwako, w swoim codziennym życiu prywatnym i zawodowym uwikłana jest w relacje z wężami, a szczególnie z jednym, twierdzącym, że jest jej matką. Jak wynika z pierwszoosobowej narracji, Hiwako węża spotkała przypadkiem, gdy idąc do pracy, po prostu na niego nadepnęła. W jednej chwili zmienił się w kobietę i od tego czasu zamieszkał w domu narratorki. Węża ma również u siebie żona Kosugi, właściciela sklepu z różańcami buddyjskimi, w którym Hiwako pracuje - jej wąż zmienia się w kobietę, nazywaną ciotką. Ma go także opat świątyni, do której Hiwako wraz ze swoim pracodawcą dostarczają różańce. Jego z kolei kobieta-wąż jest doskonałą żoną i niezrównaną, jak twierdzi opat, kochanką. Posiadanie węża we własnym domostwie i uleganie jego urokowi nie jest w rzeczywistości powieściowej Kawakami czymś nadzwyczajnym.

Wąż jest stworzeniem znanym kulturze japońskiej od zarania dziejów, a jego symbolika jest wieloznaczna. Uznawany za bóstwo wodne opiekujące się rybakami, sprawuje też pieczę nad ludzkim domostwem. Może zarówno 
przynieść człowiekowi szczęście, jak i sprowadzić na niego nieszczęście. Wąż nie ma jednoznacznych konotacji negatywnych czy pozytywnych, a spotkanie z nim uznawane jest współcześnie raczej za dobry znak (Sowińska-Mitsui 2012: 123). W wierzeniach ludowych kojarzony bywa z oszukańczymi lub nieczystymi myślami. Może zmieniać się w mężczyznę lub kobietę i często symbolizuje erotyczne fantazje i pożądanie (Tyler 2012: 43). Jednak pierwotne znaczenie węża odsyła przede wszystkim do jego mocy witalnych. W najstarszych wierzeniach japońskich wąż, chowający się pod ziemię w okresie zimy, gdy cała natura zamiera, i pojawiający się ponownie wiosną, wraz z powrotem życia, uznawany był za wcielenie bóstwa i stanowił symbol odrodzenia życia oraz życia jako takiego ${ }^{11}$ (Kaneko i in. 1992: 68). W tym sensie witalistyczna symbolika węża z powieści Kawakami zbiega się z posthumanistyczną afirmację zoe, jaką Braidotti prezentuje w swojej pracy Transpositions. The Nomadic Ethics. Braidotti stwierdza, że „to, co teraz powraca, to inny żyjącego ciała w jego humanistycznej definicji: drugie oblicze bios, czyli zoe, generatywna witalność pozaludzkiego i przedludzkiego lub zwierzęcego życia" (cyt. za Bakke 2012: 40). Takie pojmowanie zoe pozwala na przeformułowanie podmiotowości, zaakceptowanie tego, co zwierzęce w człowieku, i wyjście naprzeciw budowaniu podmiotowych relacji ludzi i nieludzi. To właśnie czyni w swojej powieści Kawakami, kiedy zaprasza zwierzęta do świata ludzkiego. Zamieniając węże w ludzi i ludzi w węże, zaciera granice między człowiekiem a zwierzęciem. Wąż Hiwako czasami występuje w swej zwierzęcej postaci i zachęca narratorkę do wspólnego odejścia do krainy węży lub śpi zwinięty w kłębek na suficie, niekiedy zaś przybiera postać kobiety, krząta się w jej domu i dba o nią troskliwie. Stosunek Hiwako do kobiety-węża jest ambiwalentny. Z jednej strony całkowite poddanie się czarowi węża budzi w niej sprzeciw. Wprawdzie zdarzyło jej się zapragnąć przemiany w węża, jednak na co dzień walczy z tym uczuciem. Jej ciało, nawiedzane przez setki małych węży, kilkakrotnie, wbrew jej woli, przetransformowało się, lecz Hiwako broni się ze wszystkich sił przed odejściem do wężowej krainy. Z drugiej strony czuje się z wężem dobrze, odczuwa przy nim ciepło i błogość: „Kobieta poklepała mnie po ramieniu, a gdy się odwróciłam, przytuliła swój policzek do mojego. Był zimny. Ogarnęło mnie poczucie błogości, jakbym miała przy sobie ulubione zwierzątko, albo jakby ktoś troskliwie okrył mnie wielkim kocem" (Kawakami 2010: 36).

11 To właśnie najprawdopodobniej w tym znaczeniu występował jako motyw zdobniczy na glinianych naczyniach jōmon doki (ok. 12 tys. lat p.n.e. do III w. p.n.e.), należących do najstarszej na świecie ceramiki japońskiej. 
Hiwako twierdzi wręcz, że mur, który dzieli ją od innych ludzi, tylko przy wężu znika. W jej bliskości z wężem zacierają się granice gatunkowe, w efekcie czego rodzi się uczucie idealnej jedności tego, co zwierzęce, i tego, co ludzkie, wraz z tym, co zwierzęce w człowieku i co ludzkie w wężu:

Przytulając się, jednocześnie mnie objęła. Jej ramiona również były chłodne. Koniuszki jej palców wyglądały tak, jakby powoli wracała do postaci węża, ale nawet jeśli tak było, nie budziło to we mnie żadnego obrzydzenia. Powiem więcej, czułam się raźniej, gdy przybierała postać węża. [...] Była mniej więcej tego samego wzrostu. Kiedy obejmowałyśmy się ramionami, tworzyłyśmy całość, jak dwie części kompletu (Kawakami 2010: 36).

Zdarzało się, że w bliskich relacjach z wężem, gdy wąż-matka oplatał ją swoim ciałem, Hiwako odczuwała strach, a jednak, jak uświadamia to sobie w wewnętrznym monologu, „na jego dnie pojawiała się jakaś niedorzeczna rozkosz" (Kawakami 2010: 55). Zrozumiała to podczas spotkania z żoną opata, która ujawniła swoją wężową, przesyconą seksualnością naturę, gdy oplotła swym ciałem Kosugę, a później Hiwako.

Do przyjemności płynącej z doznań cielesnych, tym razem noszących wyraźne znamiona odczuć erotycznych, Hiwako powraca raz jeszcze, gdy wspomina swoje bliskie kontakty z mężczyznami. Podczas aktu seksualnego wzajemne wyzbycie się ludzkich kształtów i wtopienie się w siebie jest dla niej ideałem. W takich chwilach jej partnerzy stają się na krótką chwilę wężami, przybierającymi różne kolory (Kawakami 2010: 42-43). Wieloznaczny, unikający jasnych określeń język prozy Kawakami sprawia, że trudno rozstrzygnąć, czy Hiwako ma tutaj na myśli jedynie fantazje seksualne, czy są to jej rzeczywiste doznania erotyczne, jakże prawdopodobne w powieści rządzącej się zasadami realizmu magicznego ${ }^{12}$.

Nadepnęłam na węża interpretowane bywa w kategoriach zmagań głównej bohaterki z własną kobiecością, poszukiwania tożsamości w relacji do matki, z jednoczesnym brakiem gotowości do przyjęcia dorosłej roli w życiu (Sowińska-Mitsui 2012: 126). Nie zmienia to faktu, że jest to również opowieść o doświadczaniu, na poziomie afektu, drzemiącego w ciele człowieka pierwiastka zwierzęcego wraz z jego nieokiełznaną siłą witalną. Zwierzę i człowiek spotykają

12 Ten aspekt prozy Kawakami nasuwa pewne skojarzenia z surrealnym wariantem realizmu magicznego odnajdywanym w utworach Leonory Carrington, pisarki, malarki i rzeźbiarki brytyjskiego pochodzenia. 
się w jednym świecie, w jednym ciele i rozpoznają swą biologiczną bliskość, nie do końca jeszcze przez człowieka akceptowalną.

Międzygatunkowe bliskie relacje, uznawane za największe tabu, odnajdywane są w legendach i mitach w każdej kulturze. W literaturze japońskiej od wczesnej starożytności istnieją niezliczone baśnie i legendy nie tylko takie, w których ludzie ulegają transfiguracji, ale też takie, w których bohaterowie ludzcy i nie-ludzcy wchodzą ze sobą w relacje intymne. Mają one nawet swą nazwę gatunkową - pierwsze $\mathrm{z}$ nich to tak zwane henshintan, opowieści o transfiguracji, drugie - irui kon'intan, opowieści o związkach międzygatunkowych ${ }^{13}$. Powszechnie znane są w Japonii historie o lisicach (kitsune) uwodzących mężczyzn, wężach (hebi) czarujących kobiety czy żurawiach (tsuru) stających się przykładnymi żonami. Przy czym nie tylko ludzie (albo bogowie w ludzkiej postaci) zmieniają się w zwierzęta, ale też zwierzęta stają się ludźmi. Ten drugi typ przemiany zdarza się rzadko w tradycji euroamerykańskiej, w której człowiek stawia się ponad zwierzęciem (Nakamura 2006: 17). Powszechna w Japonii akceptacja dla cielesnej i duchowej przemiany zwierzęcia w człowieka wydaje się mieć związek z oryginalnym brakiem istnienia w tym kraju pojęcia „natura” w znaczeniu zachodnim, a co za tym idzie, brakiem wyraźnie homocentrycznego stosunku do rzeczywistości, który w kulturze zachodniej przejawia się reifikacją natury i stawianiem człowieka ponad nią. Współczesne japońskie słowo shizen weszło w Japonii w użycie w znaczeniu odpowiadającym zachodniej „naturze” dopiero w drugiej połowie XIX wieku, wraz z przyjęciem przez nią euroamerykańskiego systemu nauk. Do tego czasu Japończycy, zgodnie z rodzimymi animistycznymi wierzeniami sinto, uznawali świat zjawiskowy za manifestację bóstw, a najbliższymi „naturze” określeniami były w przednowoczesnej Japonii takie pojęcia jak ametsuchi (niebo i ziemia) czy ikitoshi ikeru mono (wszystkie istoty żywe, wszystko, co na tym świecie żyje) (zob. Nihonjin no shizenkan 1996: 17). W tak konceptualizowanej rzeczywistości człowiek i natura nie byli postrzegani ani jako wyraźni antagoniści, ani jako przyjaciele. Człowiek, uznawany za część kosmosu, istniał równorzędnie z innymi bytami, stanowiąc element świata, w którym granice cielesności pozostawały płynne.

13 Zagadnieniu transfiguracji ludzkich i zwierzęcych oraz związków międzygatunkowych w japońskich bajkach i legendach poświęcona jest w całości obszerna praca Nakamury Teiriego (zob. Nakamura 2006). 


\section{Ludzie i nieludzie w czasach ekozagłady - Kret i Niedźwiedzi bóg 2011}

Podczas gdy tematyka omówionych wcześniej utworów Kawakami, powstałych w ostatniej dekadzie XX wieku, dotyczyła przede wszystkim weryfikowania granic dzielących podmiot ludzki i nie-ludzki, bez wyraźnego zwrócenia uwagi na skalę zmian postępujących w środowisku, XXI wiek przeniósł bohaterów „opowieści zmyślonych” do współczesnego nam świata antropocenu - czasu destrukcyjnych i nieodwracalnych zmian dla biosfery, epoki wymierania gatunków i wyniszczających człowieka epidemii, coraz częstszych i intensywniejszych kataklizmów naturalnych i zagrożenia zagładą atomową. Niepokój i strach przed końcem świata takiego, jaki człowiek znał do tej pory, stał się dominującym ludzkim uczuciem. Jak w tej dystopijnej rzeczywistości kształtują się relacje ludzi i nieludzi? Czy troska o Ziemię i wspólną koegzystencję nadal pozostaje celem, o który warto walczyć?

Odpowiedzi na te pytania Kawakami poszukuje w opowiadaniach Kret i Niedźwiedzi bóg 2011. Miejscem akcji pierwszego z nich, napisanego w początkach nowego millenium ${ }^{14}$ i przesiąkniętego atmosferą postapokaliptycznego niepokoju, jest Tokio. Miasto zamieszkują dwa rodzaje ludzi - jedni wydają się funkcjonować zupełnie normalnie, drudzy, enigmatyczni are (dosł. 'tamci'), są słabymi, bezwolnymi istotami, zobojętniałymi na wszystko. Jedynym uczuciem, jakie okazują, jest rozpacz w obliczu śmierci, która ich dziesiątkuje. Ludzi tych wypełnia pustka, są przerażeni i zachowują się, jakby nie mieli sił ani żyć, ani umrzeć. Zdziczali, nie zajmują się dziećmi, które zdarza im się wydać na świat. Urodzone przez nich niemowlęta, podobne do kretów i rosnące w błyskawicznym tempie, nie wykazują oznak uczuć wyższych.

Główny bohater opowiadania, kret posiadający ludzką inteligencję i ponadludzkie moce, żyje głęboko pod ziemią wraz ze swoją krecią żoną. Ze wszystkich kretów, których kiedyś było na ziemi wiele, pozostała już tylko ich jedna rodzina wraz z rodzicami i rodzeństwem mieszkającym na Kiusiu. Kret jest nieco mniejszy od człowieka, pokryty gęstą sierścią, ma ostre pazury i na co dzień pracuje w biurze z ludźmi, którym bardzo nisko się kłania. W pierwszoosobowej narracji opowiada, jak wygląda jego dzień, co robi od rana przez noc, aż po świt. Pewną część jego życia zajmuje praca zawodowa. Stosunki ze współpracownikami wydają się poprawne, lecz to tylko fasada - w rzeczywistości, jak twierdzi, ludzie zawsze byli nastawieni do kretów wrogo:

14 Opowiadanie to po raz pierwszy zostało opublikowane w 2001 roku, w 2. numerze czasopisma literackiego „Bungakukai” (Kawakami 2001b). W 2002 roku znalazło się, jako jedno z ośmiu historii fantastycznych w zbiorze Ryūgū (Smoczy Pałac), wydanym przez Wydawnictwo Bungei Shunjū. 
Ludzie mnie nie lubią. I tak było od dawna. W czasach moich przodków było nie do pomyślenia, żebyśmy żyli razem z ludźmi na co dzień, tak jak ja teraz. Ludzie nie cierpieli mojego rodu. Wystarczyło, że nas zauważyli, od razu strzelali, dźgali łopatą, rozsypywali truciznę. Straszne to były czasy (Kawakami 2005: 131).

Lecz obecnie ludzie, pomimo że w głębi serca nadal czują do kretów niechęć i większość uważa je za szkodniki, najwyraźniej ich potrzebują - dlatego tė̇ tolerują kreta w biurze. On sam przyznaje, że niezbyt rozumie ludzi. A przy tym jest dumny ze swojej zwierzęcości i czuje się równy ludziom. Gdy spotkani włóczędzy zarzucają mu, że zadziera nosa, choć jest tylko zwierzęciem, odpowiada rezolutnie: „A co, przecież ludzie też są zwierzętami” (Kawakami 2005: 126). Czasem wręcz z premedytacją prowokuje w biurze sytuacje, w których okazuje ludziom swoją wyższość:

Piję letnią herbatę i upuszczam czarkę. Czasami robię to specjalnie. W ludziach wzbiera wtedy nienawiść, lecz nie okazują mi jej, tylko zbierają resztki czarki w atmosferze aż gęstej od bijącej do mnie niechęci. A ja, z miną jak gdyby nigdy nic, wpatruję się w liczby na ekranie komputera (Kawakami 2005: 132).

Zupełnie inaczej kret zachowuje się jednak w stosunku do dziwnych, przepełnionych strachem are o pustych, nieobecnych spojrzeniach. Ci odrzuceni przez społeczeństwo słabi, chorzy ludzie, których z roku na rok przybywa, znajdują u kreta zrozumienie i pomoc. Wykazując się altruizmem i wyrozumiałością, kret zbiera ich w różnych zakamarkach miasta i przynosi do siebie, pod ziemię, by opiekować się nimi niczym dobry Samarytanin. Wraz z żoną gotuje im pożywne jedzenie, karmi, okrywa ciepłymi kocami. Na ogół ludzie umierają - i tych kret wrzuca do głębokiego dołu, służącego za miejsce pochówku jeszcze w czasach jego przodków. Tym natomiast, którzy zdrowieją, pozwala zostać u siebie, aż nabiorą sił i będą mogli odejść.

W ukazanym w opowiadaniu Kret postkatastroficznym świecie, w którym człowiek uległ dziwnej mutacji, odwrócony został normalny w antropocentrycznym świecie porządek - to nie zwierzęta zależne są od ludzi, lecz ludzie od zwierząt; to nie ludzie, lecz zwierzęta wykazują się wysoką inteligencją i zaradnością życiową. Ich stosunki są nie najlepsze, by nie powiedzieć - wrogie. Interpretacja Kreta nie jest łatwa $\mathrm{z}$ uwagi na jego otwarte zakończenie (często spotykane w utworach Kawakami). Kret kontynuuje swoją wolontariacką pracę zbieracza osłabionych ludzi, którym pomaga powrócić, choćby na krótko, do 
sił. Opowiadanie to można odczytać jako ostrzeżenie przed pychą człowieka i nadmierną wiarą we własną moc, która doprowadziła ludzkość na skraj przepaści. A jednocześnie dostrzegalna jest w nim nadzieja, że w obliczu ostatecznej katastrofy tym, kto przyjdzie człowiekowi z pomocą, będą być może zwierzęta, przedstawiciele lekceważonej przez człowieka natury.

Nie znamy genezy zgubnych w skutkach zmian, które w opowiadaniu Kret doprowadziły do dehumanizacji gatunku ludzkiego. Nie wiemy, czy postępujące wymieranie człowieka zostało spowodowane wirusem, czy jakąś inną katastrofalną przyczyną, która zaburzyła ekosystem. Natomiast w opowiadaniu Niedźwiedzi bóg 2011 Kawakami konfrontuje nas z zagładą w jej konkretnym wymiarze - jest nim skażenie atomowe. Opowiadanie to zostało napisane około dwóch tygodni po katastrofie nuklearnej w Fukushimie z 11 marca 2011 roku i stanowiło jedną z pierwszych licznych odpowiedzi literackich na wydarzenie, które, obok Czarnobyla, stało się współcześnie figurą nuklearnej ekozagłady ${ }^{15}$. Kawakami osiągnęła w nim wstrząsający efekt, nakładając na siebie, na zasadzie podwójnie naświetlonej kliszy, dwa obrazy. Tym pierwszym jest bukoliczna wizja świata, znana z opowiadania Niedźwiedzi bóg z 1994 roku, drugi to obraz świata po skażeniu atomowym. Choć nazwa Fukushimy ani określenie „katastrofa nuklearna" nie pada w Niedźwiedzim bogu 2011 ani razu, kontekst historyczny i sytuacyjny sprawia, że czytelnik doskonale wie, o czym jest to opowiadanie. Zmiany wprowadzone w oryginalnym tekście Niedźwiedziego boga są śladowe. Ten sam niedźwiedź zaprasza swoją sąsiadkę nad rzekę, wspólny spacer też jest udany. A jednak, jako że wszystko dzieje się po „tamtym zdarzeniu” (ano koto, dosł. 'tamta rzecz'), wszystko jest zupełnie inne. W budynku, do którego wprowadził się niedźwiedź, pozostały już tylko trzy rodziny, na zewnątrz ludzie noszą ubrania ochronne, z powodu dekontaminacji gleby pola ryżowe zostały rozkopane. Nad rzeką, gdzie kiedyś było mnóstwo ludzi, teraz stoi tylko dwóch mężczyzn, dzieci nie ma w ogóle, nikt się nie kąpie. Złowionych ryb nie można już jeść, gdyż żywią się glonami, w których łatwo kumuluje się cez. Język opowiadania niektórych fragmentów nabiera charakteru naukowego, bliskiego niemal specjalistycznemu żargonowi fizyków nuklearnych. Padają takie terminy jak licznik Geigera, stront, pluton, cez, jednostki promieniowania radioaktywnego. Napromieniowanie narratorka mierzy sobie codziennie przed snem:

15 Awaria reaktora Fukushima Daiichi została oceniona w skali INES na równi z awarią czarnobylską. Więcej na temat postnuklearnych naturo-kulturowych zmian w Fukushimie zob. artykuł Aleksandry Brylskiej Radioaktywne kwiaty wiśni. Relacja Japończyków ze skażonymi obszarami wokół elektrowni Fukushima Daiichi (Brylska 2020: 135-151). 
[...] szacowana dawka promieniowania zewnętrznego - 30 mikrosiwertów, promieniowania wewnętrznego - 19 mikrosiwertów. Szacowana skumulowana dawka promieniowania zewnętrznego od początku roku do dzisiaj - 2900 mikrosiwertów [...] (Kawakami 2019b: 49).

Brzmi to wszystko złowrogo. Stosunek większości ludzi do niedźwiedzia też jest mało przyjazny, podobnie jak w pierwszym opowiadaniu. Pewnej otuchy dodaje jednak brak jakiejkolwiek zmiany w relacji narratorki i niedźwiedzia. Niedźwiedź nie zostaje w tym postkatastroficznym świecie sam. Spędza udany dzień z narratorką, która na pożegnanie przytula się do niego, choć ma świadomość, że powierzchnia jego ciała może być silnie napromieniowana. Niedźwiedź pozostaje w świecie ludzi, a narratorka nadal nie potrafi sobie wyobrazić niedźwiedziego boga, którego opiece została powierzona.

W posłowiu do zestawionych ze sobą w tomie Niedźwiedzi bóg 2011 opowiadań Kawakami zastanawia się nad odwieczną więzią mieszkańców Japonii $\mathrm{z}$ naturą, symbolizowaną przez wiarę w istnienie ducha lub boskiej obecności we wszystkich żywych istotach, zjawiskach i przedmiotach. Zadaje jednocześnie pytanie, utrzymane w baśniowej konwencji, co bóg uranu pomyśli o współczesnych ludziach, którzy dla swoich egoistycznych korzyści zapominają o tej więzi i eksploatują uran nadmiernie, igrają z energią jądrową, ryzykując, że zmienią Ziemię w planetę, na której życie stanie się niemożliwe.

W utworach Kawakami Hiromi - tych przedstawionych w artykule, ale te $\dot{z}$ $\mathrm{w}$ wielu innych - odnajdujemy świat ukazany z perspektywy nieantropocentrycznej, zdecydowanie większy niż ludzki. Japońska pisarka czyni bohaterami swoich powieści i opowiadań byty wszelkiego typu. Nie przeciwstawia ich przy tym człowiekowi, lecz daje równe prawa do istnienia, wychodząc naprzeciw reprezentatywnym ideom nurtu posthumanizmu krytycznego. Czerpiąc lekcje z nauk przyrodniczych, Kawakami dostrzega cielesną łączność tego, co ludzkie i nie-ludzkie. Bohaterowie jej prozy stanowią nierozerwalną część natury i tworzą wspólny z nią kolektyw. Przetrwanie tego kolektywu we współczesnym, stechnologizowanym świecie, w którym człowiek staje się coraz bardziej zachłanny i wyraźnie zatraca więź z naturą, jest jednak zagrożone. Kawakami ostrzega człowieka przed skutkami jego zgubnej działalności, nie tracąc przy tym nadziei, że nie dopuści on do najgorszego. „Bo przecież życie, samo w sobie, to wielka radość" - konstatuje w ostatnich słowach posłowia do Niedźwiedziego boga 2011 (Kawakami 2019b: 59). 


\section{| Bibliografia}

Araki Narumi (2011), Kawakami Hiromi. „Kamisama”, „Sōjō no chūshoku” ron - „Kuma”no ikizurasa o tōshite miete kuru mono (Rozprawa o „Niedźwiedzim bogu” i „Lunchu na trawie”. Czego dowiadujemy się poprzez trudności życiowe „Niedźwiedzia”), „Sapporo Daigaku Sōgō Ronsō” (Pismo Uniwersytetu Sapporo), nr 32, s. 232 (1)-216 (17), https://tinyurl.com/yugnpmzj, [dostęp: 12.02.2021].

Bakke Monika (2010), Posthumanizm: człowiek w świecie większym niż ludzki, w: Człowiek wobec natury - humanizm wobec nauk przyrodniczych, red. Jacek Sokolski, Wydawnictwo Neriton, Warszawa, s. 337-357.

Bakke Monika (2012), Bio-transfiguracje. Sztuka i estetyka posthumanizmu, Wydawnictwo Naukowe UAM, Poznań.

Bakke Monika (2020), Gdy stawka jest większa niż życie. Sztuka wobec mineralno-biologicznych wspólnot, „Teksty Drugie”, nr 1, s. 165-185.

Braidotti Rosi (2006), Transpositions. On Nomadic Ethics, Polity Press, Cambridge.

Braidotti Rosi (2014), Po człowieku, przeł. Joanna Bednarek, Agnieszka Kowalczyk, PWN, Warszawa.

Brylska Aleksandra (2020), Radioaktywne kwiaty wiśni. Relacja Japończyków ze skażonymi obszarami wokót elektrowni Fukushima Daiichi, „Teksty Drugie”, nr 1, s. 135-151.

Derrida Jacques (2004), Gościnność nieskończona, przeł. Paweł Mościcki, „Przegląd Filozoficzno-Literacki”, nr 3(9), s. 257-251.

Gajewska Grażyna (2013), O przedmiotach nacechowanych erotycznie z perspektywy studiów nad rzeczami, „Teksty Drugie”, nr 1/2, s. 45-59.

Haraway Donna (2008), When Species Meet, University of Minnesota Press, Minneapolis.

Haraway Donna (2012), Manifest gatunków stowarzyszonych, przeł. Joanna Bednarek, w: Teorie wywrotowe. Antologia przekładów, red. Monika Gajewska, Wydawnictwo Poznańskie, Poznań, s. 241-26o.

Kaneko Hiromasa i in. (1992), Nihonshi no naka no dōbutsu jiten (Zwierzęta w historii Japonii. Słownik), Tōkyōdō Shuppan, Tōkyō.

Kawakami Hiromi (2001a), Sōjō no chūshoku (Lunch na trawie), w: taż, Kamisama (Niedźwiedzi bóg), Chūō Kōron, Tōkyō, s. 173-191.

Kawakami Hiromi (2001b), Ugoromochi (Kret), „Bungakukai”, nr 2, s. 42-52.

Kawakami Hiromi (2005), Ugoromochi (Kret), w: taż, Ryūgū (Smoczy Pałac), Bunshun Bunko, Tōkyō, 119-144.

Kawakami Hiromi (2009), Hazuki san no koto (Pani Hazuki), w: taż, Hazuki san no koto (Pani Hazuki), Kōdansha, Tōkyō, s. 171-179. 
Kawakami Hiromi (2010), Nadepnęłam na węża, w: taż, Nadepnęłam na węża, przeł. Barbara Słomka, Karakter, Kraków, s. 9-61.

Kawakami Hiromi (2019a), Niedźwiedzi bóg (Kamisama), w: taż, Niedźwiedzi bóg, przeł. Beata Kubiak Ho-Chi, Tajfuny, Warszawa, s. 23-33.

Kawakami Hiromi (2019b), Niedźwiedzi bóg 2011, w: taż, Niedźwiedzi bóg, przeł. Beata Kubiak Ho-Chi, Tajfuny, Warszawa, s. 37-49.

Kawakami Hiromi, Numano Mitsuyoshi (2012), Sekai wa yuragi, genjitsu to gensō no sakaime mo yuraide iru Nihon bungaku no hon'yakukatachi to shōsetsu "Fūka" o kataru (Świat się chwieje i granice pomiędzy rzeczywistością a fantazją też się chwieją - o powieści "Fūka” z tłumaczami japońskiej literatury), https://tinyurl.com/vt48jzwz [dostęp: 12.02.2021].

Nakamura Teiri (2006), Nihonjin no dōbutsukan. Henshintan no rekishi (Stosunek Japończyków do zwierząt. Historia opowieści o transfiguracji), Bīngu Netto Puresu, Tōkyō.

Nihonjin no shizenkan (Japońskie pojęcie natury) (1996), w: Eigo de hanasu Nihon no kokoro. Keys to the Japanese Heart and Soul (Japońskie serce po angielsku. Klucz do japońskiego serca i duszy), wybór artykułów z Eibun Nihon Daijiten (Wielki słownik japoński po angielsku), Kodansha International, Tōkyō, s. 17-19.

Latour Bruno (2009), Polityka natury. Nauki wkraczaja do demokracji, przeł. Agata Czarnacka, wstęp Maciej Gdula, Wydawnictwo Krytyki Politycznej, Warszawa.

Regan Tom (1980) Prawda i krzywda zwierząt, przeł. Zygmunt Nierada, „Etyka”, nr 18, s. 87-118, https://tinyurl.com/pemrn7sv [dostęp: 12.02.2021].

Ryder Richard (1980), Szowinizm gatunkowy, czyli etyka wiwisekcji, przeł.

Zbigniew Szawarski, „Etyka”, nr 18, s. 39-47, https://tinyurl.com/ymsr5k2u [dostęp: 12.02.2021].

Shimizu Yoshinori (2003), Ishu e no kensō (Pociąg do innych gatunków), „Yurika”, Rinji sōkangō (wydanie specjalne), Kawakami Hiromi dokuhon (Hiromi Kawakami - przewodnik), nr 9, s. 72-79.

Singer Peter (2004), Wyzwolenie zwierząt, przeł. Anna Alichniewicz, Anna Szczęsna, PIW, Warszawa.

Singer Peter, red. (2011), W obronie zwierząt, przeł. Monika Betley, Czarna Owca, Warszawa.

Soper Kate (2014), Odrzucanie i odzyskiwanie „natury” na przykładzie gender $i$ animal studies, przeł. Anna Barcz, w: Zwierzęta, gender, kultura. Perspektywa ekologiczna, etyczna i krytyczna, red. Anna Barcz, Magdalena Dąbrowska, E-naukowiec, Lublin, s. 37-46, https://tinyurl.com/56s34856 [dostęp: 10.02.2021]. 
Sowińska-Mitsui Renata (2012), Cztery razy kobiecość, w: Oblicza współczesnej japońskości. Literatura - film - spektakl, red. Radosław Siedliński, Iwona Merklejn, Wydawnictwo PJWSTK, Warszawa, s. 93-132.

Tyler Royall (2012), Wstęp, w: tenże, Baśnie japońskie, przeł. Marta Komorowska/ Quendi Laungage Services, Wydawnictwo G+J RBA, Warszawa, s. 7-48.

Uei Na (2005), Kawakami Hiromi. Nenpyō (Kalendarium życia i twórczości Hiromi Kawakami), w: Kawakami Hiromi (Hiromi Kawakami), Gendai josei sakka dokuhon, 4 (Przewodnik po współczesnych pisarkach japońskich, 4), red. Hara Zen, Kanae Shobō, Tōkyō, s. 147-151.

Weil Kari (2014), Zwrot ku zwierzętom. Sprawozdanie, przeł. Piotr Sadzik, w: Zwierzęta, gender, kultura, Perspektywa ekologiczna, etyczna i krytyczna, red. Anna Barcz, Magdalena Dąbrowska, E-naukowiec, Lublin, s. 15-35, https://tinyurl.com/56s34856 [dostęp: 10.02.2021].

Wolfe Cary (2010), What is Posthumanism, University of Minnesota Press, Minneapolis.

Wolfe Cary (2013), Animal studies, dyscyplinarność i (post)humanizm, przeł. Karolina Krasuska, „Teksty Drugie”, nr 1/2 , s. 125-153.

\section{| Abstrakt}

\section{Beata Kubiak Ho-Chi}

\section{Krajobrazy posthumanistyczne w prozie Hiromi Kawakami}

Hiromi Kawakami (ur. 1958) tworzy w swoich powieściach i opowiadaniach oryginalny świat fantazji, zamieszkiwany na równych prawach przez ludzi i byty nie-ludzkie. Ich uniwersa przenikają się, a granice taksonomiczne, estetyczne, etyczne zanikają. W wyniku przesunięcia uwagi z człowieka na płazy, gady, ssaki, rośliny, a nawet materię nieorganiczną, ludzki podmiot ulega w utworach Kawakami decentracji, a antropocentryczny porządek normatywny zostaje zaburzony. Sprawia to, że proza Kawakami wpisuje się wyraźnie w posthumanistyczny dyskurs literacki obecny w humanistyce środowiskowej. W artykule analizuję takie utwory Kawakami, jak Niedźwiedzi bóg, Niedźwiedzi bóg 2011, Nadepnęłam na węża, Ugoromochi, oscylujące pomiędzy baśnią a fikcją spekulatywną. Stanowią one świadectwo silnej obecności we współczesnej literaturze japońskiej tematów istotnych dla człowieka doby antropocenu, do których należy kolektywne współistnienie ludzi i nie-ludzi, związek natura - kultura czy świadomość ekologiczna. 
Słowa kluczowe: Hiromi Kawakami, posthumanizm krytyczny, natura - kultura, Fukushima

\section{| Abstract \\ Beata Kubiak Ho-Chi \\ Posthumanistic Landscapes in the Prose of Hiromi Kawakami}

Hiromi Kawakami (born 1958) creates in her novels and short stories an original world of fantasy, inhabited with equal rights by human and non-human beings. Their universes mix with each other, obliterating taxonomic, aesthetic and ethical boundaries. As a result of the shift of focus from humans to amphibians, reptiles, mammals, plants and even inorganic matter, the human subject is decentered in Kawakami's works, and the anthropocentric normative order is disturbed. It makes Kawakami's prose fit well into the posthuman literary discourse present in the environmental humanities. In the article, I analyze such works by Kawakami as God Bless You, God Bless You 2011, A Snake Stepped On and Mogera Wogura, oscillating between a fairy tale and speculative fiction. They testify to the strong presence in contemporary Japanese literature of such topics, important for man of the Anthropocene, as the collective coexistence of humans and non-humans, the relationship between nature and culture, or environmental awareness.

Keywords: Hiromi Kawakami, critical posthumanism, nature-culture, Fukushima

\section{| Biogram}

Beata Kubiak Ho-Chi - dr hab., prof. ucz., Uniwersytet Warszawski, Katedra Japonistyki. Absolwentka japonistyki UW oraz studiów pomagisterskich I.N.A.L.C.O w Paryżu. Odbyła staże badawcze na Uniwersytecie Tokijskim oraz w Międzynarodowym Ośrodku Badań nad Kulturą Japonii (Nichibunken, Kioto). Specjalizuje się w dziedzinie japońskiej literatury nowoczesnej, teatru, estetyki, przekładu, animal studies. Opublikowała m.in.: Mishima Yukio. Estetyka klasyczna w prozie i dramacie 1941-1960 (2004), Japonia okresu Meiji. Od tradycji ku nowoczesności (red., 2006), Estetyka i sztuka japońska. Wybrane zagadnienia (2009), Tragizm w japońskim teatrze lalkowym bunraku (2011), Est Asian Theatres (współredakcja, 2017), Zwierzęta w kulturze japońskiej (współredakcja, 2018).

E-mail: b.kubiakhochi@uw.edu.pl

ORCID: oooo-0003-1162-7469 